\title{
ASSESSMENT OF MIX PROPORTIONS FOR DEVELOPING LIGHTWEIGHT CEMENTITIOUS COMPOSITES WITH WOOD WASTES ${ }^{1}$
}

\author{
Monica Garcez ${ }^{2 *}$, Estela Garcez ${ }^{3}$, Aline Machado ${ }^{4}$ and Darci Gatto ${ }^{5}$
}

\footnotetext{
${ }^{1}$ Received on 20.01.2016 accepted for publication on 11.11.2016.

${ }^{2}$ Universidade Federal do Rio Grande do Sul, Departamento Interdisciplinar, Tramandaí, RS - Brasil. E-mail: <monica.garcez@ufrgs.br>.

${ }^{3}$ Universidade Federal de Pelotas, Centro de Engenharias, Pelotas, RS - Brasil. E-mail: <estelagarcez@gmail.com>.

${ }^{4}$ Universidade Federal de Pelotas, Graduanda em Engenharia Civil, Pelotas, RS - Brasil. E-mail: <ali.oli.edi@bol.com.br>.

${ }_{5}^{5}$ Universidade Federal de Pelotas, Engenharia Industrial Madeireira, Pelotas, RS - Brasil. E-mail:<darcigatto@yahoo.com>.

*Corresponding author.
}

\begin{abstract}
The main objective of this work was to assess mix proportions for developing lightweight cementitious composites, manufactured with Eucalyptus grandis sawdust. Different wood:cement, water:cement and admixture:cement ratios were used to evaluate physical (water absorption, void ratio and density) and mechanical (compressive strength, static and dynamic modulus of elasticity) properties of the cement-wood composites. Results shows that, bulk density is directly proportional to the compressive strength and elastic modulus, and inversely proportional to the percentage of timber, considering composites with same water:cement ratio, without superplasticizer. The performance of the cement-wood composites, regarding mechanical properties, can be improved if superplasticizer is used to increase paste fluidity. Higher values of bulk density are related to lower void ratio and water absorption and higher compressive strength and modulus of elasticity.
\end{abstract}

Keywords: Eucalyptus grandis; Sawdust; Cement-wood.

\section{AVALIAÇÃO DE TRAÇOS PARA DESENVOLVIMENTO DE COMPÓSITOS CIMENTÍCIOS LEVES COM RESÍDUOS DE MADEIRA}

\begin{abstract}
RESUMO - O objetivo desse trabalho foi avaliar traços para o desenvolvimento de compósitos cimentícios leves, fabricados com serragem de Eucalyptus grandis. A partir de variações nos proporcionamentos madeira:cimento, água:cimento e aditivo:cimento, foram avaliadas propriedades fisicas (absorção, índice de vazios e massa específica) e mecânicas (resistência à compressão e módulo de elasticidade estático e dinâmico) dos compósitos cimentomadeira. Os resultados mostraram que para compósitos com mesma relação água:cimento, sem utilização de superplastificante, a massa especifica é diretamente proporcional à resistência à compressão e ao módulo de elasticidade, e, inversamente proporcional percentual de madeira. O superplastificante, utilizado com a função de aumentar a fluidez da pasta, melhora o desempenho compósitos com relação às suas propriedades mecânicas. Valores mais elevados de massa especifica estão relacionados com mais baixos índices de vazios e absorção de água, bem como a resistências à compressão e módulos de elasticidade mais elevados.
\end{abstract}

Palavras-chave: Eucalyptus grandis; Serragem; Cimento-madeira 


\section{INTRODUCTION}

Forest-based industries generally have low yields. As wood is converted and used for different purposes, a large amount of waste is generated, especially in the primary processing industries such as woodworking. As the milling sites are often located away from main consumer centers and due to the lack of regulation and control in many countries, sawmill wastes are often inadequately disposed (Barbosa et al., 2014; Ronquim et al., 2014).

Sawdust is a biodegradable material. However, its deposition in natura can cause several problems to agriculture and forestry due to the long time required for its natural degradation and to the great volumes often deposited in the same landfill. The sawdust chemical characteristics such as salinity, presence of toxic substances, $\mathrm{pH}$ and nitrogen demands may cause severe plant injury. On the other hand, if used as a civil construction material it can help to reduce the demand for raw material and energy, while supporting the woodworking sector to pursue a more sustainable path regarding the waste destination (Fagundes, 2003).

Previous studies on the use of wood residues (as fibers or particulates) have demonstrated their potential for use as reinforcement or fillers in cementitious composites (Lin et al., 1994; Pehanicha et al., 2004; Fan et al., 2012; Ashori et al., 2012; Torkaman et al., 2014; Bertolini et al., 2014). These composites can be used in a wide range of applications due their low density, low thermal conductivity, fire resistance, impermeability and mechanical strength which, although not as high as the concrete strength, is suitable for applications in thin panels, masonry blocks and as filler elements for slabs, often used in civil construction (Pimentel et al., 2006). A recent work has also discussed the production of cement-wood composites with improved durability, dimensional stability and biodegradation resistance (Frybort et al., 2008). The main source of vegetable degradation in the natural environment is the biological attack by xylophagous fungi, but in the case of cementwood composites, the cement matrix presents alkaline $\mathrm{pH}$, being able to inhibit the action of biodegradable agents (Savastano Jr., 2000).

In Brazil, $72.25 \%$ of the planted exotic forests are in Southern and Southeastern regions. There are 6.66 million hectares planted in the country, being 76.6\% of Eucalyptus and $23.4 \%$ of Pinus (ABRAF, 2013). The high concentration in these regions is justified by the location of the main industrial plants of pulp and paper, wood panels and processed wood, charcoal and steel. With over 700 species, the genus Eucalyptus has been a great alternative for forest-based industries in Brazil, mainly due to its adaptability to environment conditions, rapid growth and high productivity and (Mendes et al., 2011; Ramos et al., 2011).

The sawn wood consumption has considerably increased in Brazil in recent years, reaching 9.2 million $\mathrm{m}^{3}$ in 2012, mainly due to the development of domestic market, stimulated by the growth of construction industry and packaging market (ABRAF, 2013). For Eucalyptus grandis sawn wood, the yield ranges from $40 \%$ to $60 \%$ depending on the sawing technique used (Cunha, 2015), which results in a high production of waste.

Apart from the wide availability, previous experimental results (Beraldo and Carvalho, 2004; Castro et al., 2014) have proven that eucalyptus residue is naturally compatible with cement, and some eucalyptus species, such as Eucalyptus grandis, do not require prior surface treatment to avoid compatibility problems in cement based composites.

Within this context, the objective of this work is to evaluate different material proportions for the development of light cement composites with Eucalyptus grandis sawdust, investigating the influence of different cement:wood, water:cement and additive:cement rates in the physical and mechanical properties of the composites.

\section{MATERIALAND METHODS}

Eucaliptus grandis sawdust ( $\mu \mathrm{un}=0.12 \mathrm{~g} / \mathrm{cm}^{3}$, maximum size of $2.36 \mathrm{~mm}$ after sieving), was obtained from a wood processing industry, located in Southern Brazil. Brazilian cement CPV-ARI (ABNT 1991) similar to Portland cement Type III - HESC - High Early Strength Cement (ASTM C150-12) was used as binder. Superplasticizer whose basic composition consists of a polycarboxylate solution in an aqueous medium (ABNT, 2011) was used in some mix proportions.

\subsection{Mix proportions}

Based on a standard mix proportion of $0.3: 0.7$ (cement:wood ratio, in volume) that corresponds to 1:0.28:0.6 (cement:wood:water, in mass), different mix proportions were defined, as shown in Table I. Initially three cement:wood ratios (20:80, 30:70 e 40:60) with 
water:cement ratio of 0,6 were used. Then, three different admixture:cement ratios ( 0.005 to 0.007 , in mass) were tested with the standard mix proportion. Finally, three more variations were considered, aiming to: i) keep the standard mix proportion, reduce the amount of water and increase the amount of admixture; ii) reduce the amount of sawdust and water from the standard mix proportion; iii) keep the standard mix proportion and increase the amount of water.

\subsection{Composites physical and mechanical properties}

Aiming to assess the influence of different mix proportions on the composites physical and mechanical properties, density was determined by measuring mass and volume of each sample, at $12 \%$ of relative humidity. Compressive strength and static modulus of elasticity tests were carried out, following procedures of NBR 7215 (ABNT, 1997) and NBR 8522 (ABNT, 2003). Dynamic modulus of elasticity was determined (ABNT 2008) through the measurement of ultrasonic pulse velocity, using a TICO Proceq ultrasonic pulse velocity testing device, with transducers of $54 \mathrm{~Hz}$, according to NBR 15630 (ABNT, 2008). Void ratio and water absorption were determined, for three selected mix proportions, according to NBR 9778 (ABNT, 2005). Tests were performed in four cylindrical samples $(50 \mathrm{mmx} 100 \mathrm{~mm})$ of each composite, at 28 days. Analysis of variance (ANOVA) was performed using the Statgraphics commercial software. Fisher's Least Significant Difference (LSD) test was used to compare the difference among the mean values for the properties at the level of 0.05 .

\section{RESULTS}

Table 2 shows experimental results of physical and mechanical properties of the composites produced with nine different mix proportions.

Table 1 - Mix proportions.

Tabela 1 - Proporcionamento dos materias.

\begin{tabular}{cccc}
\hline & Proportioning & \\
\hline Composites & Cement:wood* & Water:cement** & Admixture:cement** \\
\hline I & $20: 80$ & 0.6 & - \\
II & $30: 70$ & & 0.005 \\
III & $40: 60$ & 0.6 & 0.006 \\
IV & $30: 70$ & & 0.007 \\
V & & 0.5 & 0.008 \\
VI & $30: 70$ & & - \\
VII & $40: 60$ & 0.7 & - \\
VIII & $30: 70$ & & \\
IX & & & \\
\hline
\end{tabular}

*in volume; $* *$ in mass.

Table 2 - Experimental results of physical and mechanical properties.

Tabela 2 - Resultados experimentais das propriedades fisicas e mecânicas.

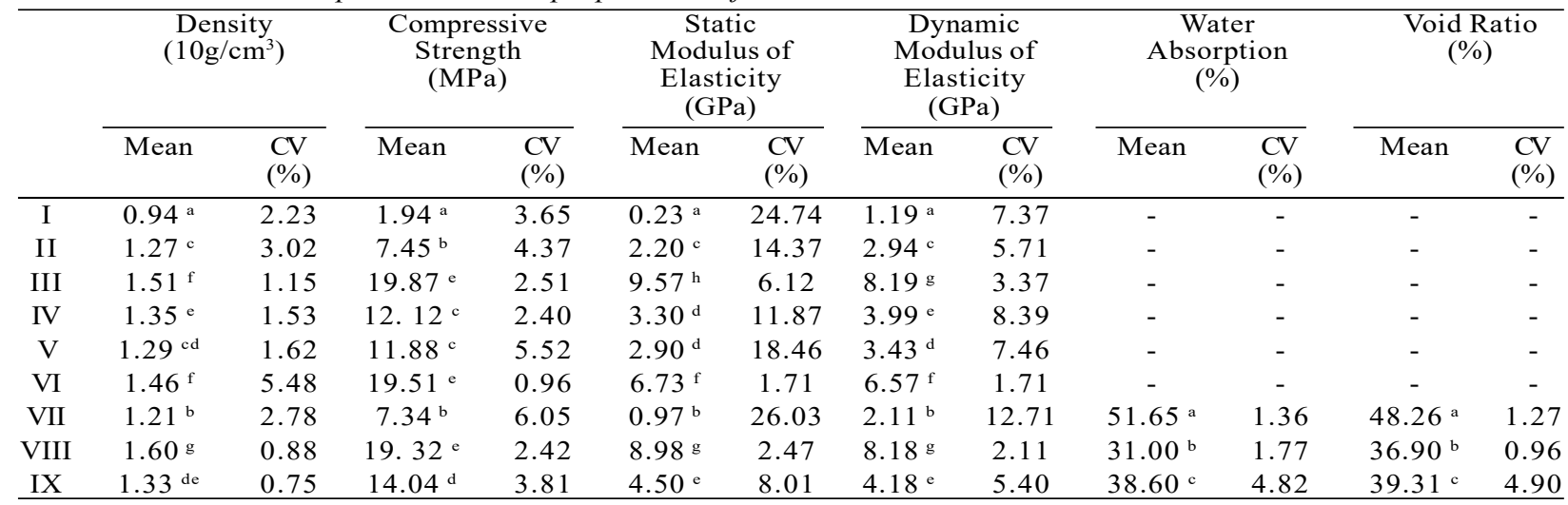

Average of four measurements. Same letters in the same columns imply treatments with equivalent means by Fisher's LSD test at the level of $0.05 ; \mathrm{CV}=$ coefficient of variation. 
The relationship between compressive strength, density, and static modulus of elasticity for nine different composites may be observed in Figure 1 that shows the values observed in the experiments as well as the ones estimated by the regression analysis.

The relationship between static and dynamic modulus of elasticity may be observed in Figure 2 that shows the values observed in the experiments as well as the ones estimated by the regression analysis.

Figure 3 shows the values observed in the experiments the and the ones estimated by the regression analysis for compressive strength, water absorption, and void ratio for composites VII, VIII e IX.

\section{DISCUSSION}

In general, reductions in the composite density are related to the increase of the percentage of wood in the composite, and lead to a reduction in the ultimate compressive strength (Jorge et al., 2004; Garcez et al., 2013; Lima and Iwakiri, 2013), as shown in Figure 1(a).

Experimental results of composites I, II and III (Table 2) with same water:cement ratio, indicate that composite I, with the highest wood:cement ratio showed the lowest density, which indicates that an increase of $10 \%$ in the wood percentage led to a decrease of about $25.98 \%$ in density. On the other hand, a decrease
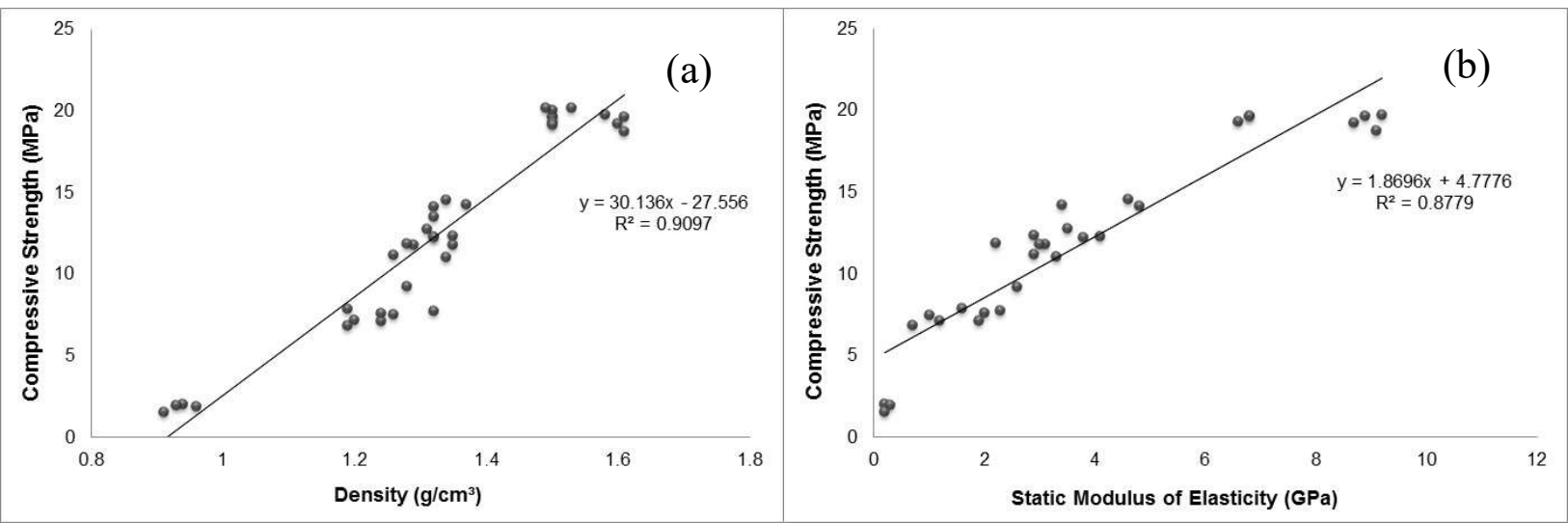

Figure 1 - Relationship between compressive strength and: (a) density (b) static modulus of elasticity.

Figura 1-Relação entre resistência à compressão e: (a) massa específica aparente; (b) módulo de elasticidade estático.

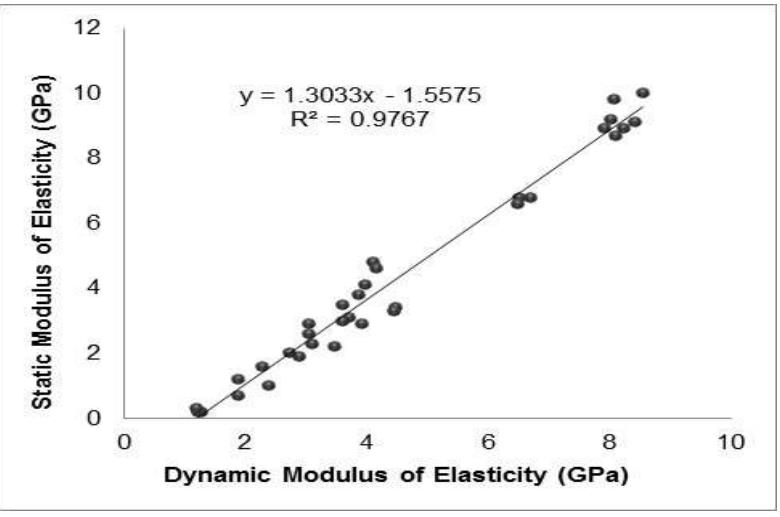

Figure 2 - Relationship between static and dynamic modulus of elasticity.

Figura 2-Relação entre módulos de elasticidade estático e dinâmico. of $10 \%$ in the wood percentage led to an increase of about $18.99 \%$ in density of composite III. Composite VIII, with same wood:cement ratio of composite III but lower water:cement ratio, which leads to a higher compressive strength, showed higher density. Compressive strength of composite III is 2.66 higher than the one of composite II and 10.24 higher than the one of composite I. However, such considerations cannot be extended to composites with different water:cement ratios or composites in which superplasticizers are used. Considering composites III and VIII, with $60 \%$ of sawdust, in volume, the attempt to increase the compression strength by reducing the amount of water in composite VIII had no effect, due to the hygroscopic behavior of the sawdust. Although density of composite VIII is the highest of all composites,

Revista Árvore. 2017;41(1):e410103 

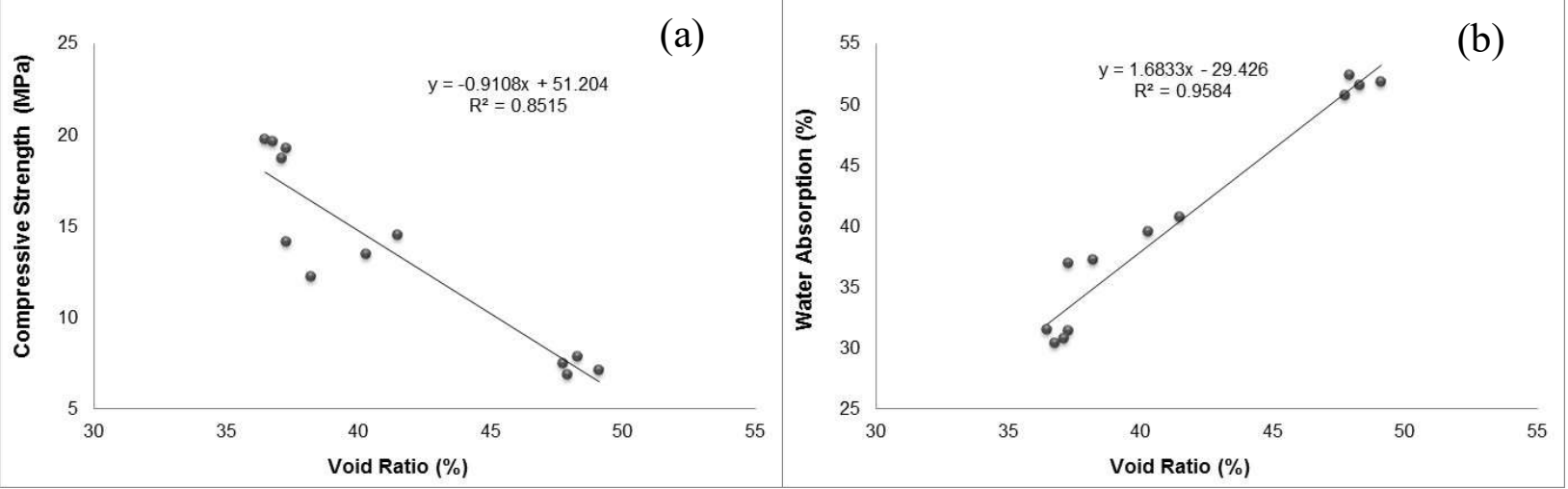

Figure 3 - Relationship between water absorption (a) and compressive strength (b) and void ratio for composites VII, VIII e IX.

Figura 3 - Relação entre absorção de água (a) e resistência à compressão (b) e indice de vazios para os compósitos VII, VIII e IX.

the amount of added water was not sufficient to garantee cement hydration and, consequently, its compressive strength did not differ statistically from the one of composite III. Regarding compressive strength, results of composites III ( $60 \%$ of wood, water:cement ratio $0.6)$, VIII ( $60 \%$ of wood, water:cement ratio 0.5$)$ and VI ( $70 \%$ of wood, water:cement ratio 0.6 and 0.007 of superplasticizer) showed no statistical difference. Compressive strength of composites with $60 \%$ and $70 \%$ of sawdust (Table II) do not restrain their use in civil engineering practical applications (Bouguerra et al., 1998), such as bricks and cement articles.

The modulus of elasticity is directly related to the stiffness of the cement-wood composites, also reflecting in the composite deformation capacity and the cracking control capacity (Christóforo, 2013). In cement pastes, the modulus of elasticity depends mainly on the water:cement ratio and its porosity (Gutierrez and Cánovaz, 1995). However, in a cement-wood composite, the ratio between pulp and aggregate, as well as the wood specie and eventual surface treatments applied to the wood particles, may also influence the modulus of elasticity. Cement-wood composites with higher densities also present higher values of modulus of elasticity and compressive strength (IwakirI et al., 2008), as evidenced by the results of composites I, II and III with same water:cement ratio (Table 2). On the other hand, reduction of density results on lighter elements that could be an advantage regarding handling and transporting. Values of modulus of elasticity for composite III were 4.35 (static) and 2.78 (dynamic) higher to the ones of composite II that was manufacturated with $10 \%$ more sawdust. As the interfacial bond strength between the fiber and the cement matrix is greatly influenced by the moisture content, since the wet fiber presents a lower bending strength, which makes it more flexible and less likely to inhibit cracking in the cement matrix (Frybort et al., 2008), it is expected that the modulus of elasticity of a cement-wood composite decreases the higher the percentage of wood. Composites III e VIII ( $60 \%$ of wood, water:cement ratio 0.6 and 0.5$)$ showed the highest values of static and dynamic modulus of elasticity. In general, for composites I, II and III, with same water:cement ratio, higher compressive strength lead to higher values of modulus of elasticity. In general, as shown in Figure 1 (b) and in Table 1 for composites I, II and III made with the same water:cement ratio, higher compressive strength leads to higher modulus of elasticity. It should be noted that although density, compressive strengths and modulus of elasticity lead to stiffer composites, lightweight composites, may offer advantages in terms of transportation, handling and assembling. The linear regression of elastic modulus data (Figure 2) showed a good correlation between static and dynamic modulus of elasticity (97.67\%), indicating that the ultrasonic wave propagation speed technique, can be used to not only determine the dynamic modulus of elasticity of the composites, but also to estimate the static modulus of elasticity of cementwood composites. 
Composites IV, V e VI were tested with the standard mix proportion of composite II and superplasticizer, in order to obtain more workable mixtures with adequate cohesion, easy molding and compressive strength higher than the one of composite II, even keeping the water:cement ratio of 0.60 . The use of superplasticizer was proposed to attenuate the hygroscopic effect of wood that removes from the mixture part of the water that would be used to cement hydration (Frybort et al., 2008). Superplasticizers are able to disperse cement particles (Yoshioka et al., 2002) and may actuate as water reducer, not affecting the workability of the mixture, or even to enhance composite workability, not affecting the water:cement ratio. The use of superplasticizer increased the compressive strength of composites IV $(62.68 \%) \mathrm{V}(58.38 \%)$ and VI $(161.8 \%)$ when compared to composite II (Table 2). The use of superplasticizer also improved the composites performance regarding static and dynamic modulus of elasticity. Indeed, superplasticizers interact chemically with binders and affect the performance of the mixture, by improving workability, leading to an increase in composites strength and/or durability (Colepardi, 2005). The percentages of superplasticizer used in the composites were $0.5 \%$, $0.6 \%$ and $0.7 \%$ of the cement mass, according to the manufacturer's recommendations $(0.3 \%$ to $1.5 \%)$.

Two more variations of the standard mix proportion, (cement:wood ratio of 30:70) was tested: first, the amount of water was decreased and the amount of admixture was increased (VII), and, second, the amount of water was increased and no admixture was used (IX). The decrease in the amount of water, in composite VII, was not effective to increase the compressive strength (Table 2 ), leading to the conclusion that the admixture, in this case, benefits the mechanical behavior of the composite just if it is used to increase workability, due to the hygroscopic behavior of wood. When compared to composites IV, V and VI, with higher amount of water, composite VII shows lower compressive strength and modulus of elasticity, confirming that the amount of water available was not enough to guarantee cement hydration. Results also show that compressive strength of composites VII (water:cement ratio of 0.5 and $0.8 \%$ of superplasticizer) and II (water:cement ratio of 0.6 and no superplasticizer) did not differ statistically. Additionally, although composite IX presents $10 \%$ more water than composites II (without admixture), IV and $\mathrm{V}$ (with admixture) it showed higher compressive strength and modulus of elasticity.

Revista Árvore. 2017;41(1):e410103
Compressive strength and dynamic modulus of elasticity of composites VIII e III, with ciment:wood ratio of 40:60 and water:cement ratio of 0.5 and 0.6 showed no significant difference (Table 2). Static modulus of elasticity reduced about $6.57 \%$ when more water was used.

There is a linear correlation, inversely proportional, between cement:wood ratio and modulus of elasticity (Frybort et al., 2008). Results of Table 2 show that the composite with $80 \%$ of sawdust showed lower modulus of elasticity when compared to those with $70 \%$ and $60 \%$ of sawdust, which also occurs in the compressive strength (Garcez et al., 2013).

Composites VII, VIII and IX were also evaluated regarding water absorption and void ratio (Table 2), since these parameters are very important to guarantee composites dimensional stability and durability, fundamental for practical applications. The mean values of water absorption and void ratio for composites VII, VIII and IX were statistically different.

Regarding water absorption and void ratio, the linear regression (Figure 3 (a)) showed a good correlation (95.84\%), indicating that both properties are directly proportional. In relation to the compressive strength, this is inversely proportional to the void ratio (Figure 3 (b)), with a correlation of $85.15 \%$. There was a statistical difference in the mean values of water absorption and void ratio for the three composites analyzed (Table 2).

Regarding composites VII and IX, both with 70\% of wood, in volume, one can observe that an increase of $10 \%$ in the water:cement ratio led to reductions of $25.26 \%$ in water absorption and $18.54 \%$ in void ratio. This behavior happened due to the higher amount of water that allowed cement hydration and led to an improvement in the mechanical properties of composite IX. For composites VII and IX, both with $70 \%$ of wood by volume, it was observed that the $10 \%$ increase in the water:cement ratio led to a reduction of $25.26 \%$ in water absorption and $18.54 \%$ in void ratio, which let to an improvement in the mechanical properties of composite IX. As already discussed, this was due to the higher availability of water for cement hydration. Composite VIII, with $60 \%$ of sawdust, showed lower values of water absorption and void ratio, as expected, due to the lower amount of wood in the composite. The increase in the water absorption, when the percentage of sawdust is high, happens due to the 
hygroscopic behavior of wood and due to the high porosity that allows voids filling by water (Torkaman et al., 2014). The effect of macroporosity in cementwood composites is related to the wood particles while mesoporosity is essentially related to the composite matrix (Bouguerra et al., 1998). Then, it is possible to consider that the intrinsic porosity of wood particles (Tessaro et al., 2015) also contribute to increase void ratio and decrease mechanical properties of cementwood composites. Additionally, high values of density are related to low void ratios and water absorption, as well as low compressive strength and modulus of elasticity, which can be confirmed by the results of composites VIII and IX (60\% and $70 \%$ of wood).

\section{CONCLUSIONS}

In this work, Eucalyptus grandis sawdust was used to develop lightweight cement composites. Several cement-wood composites were produced and, based on the experimental results, the following can be concluded:

Density is directly proportional to compressive strength and modulus of elasticity and inversely proportional to wood:cement ratio. However, due to the hygroscopic behavior of wood, this conclusion cannot be applied to composites with different water:cement ratio or even o composites that have been produced with superplasticizers.

Ultrasonic pulse velocity may be used to evaluate physical and mechanical properties of cement-wood composites in loco, with no need of performing laboratory tests.

The superplasticizer, used to increase workability, helped to improve the mechanical properties of the cement-wood composites, since it allowed cement particles dispersion and, consequently allowed cement hydration.

High values of density are related to low values of void ratio and water absorption and high values of compressive strength and modulus of elasticity.

Water absorption and void ratio are directly proportional. Composites with high percentages of wood show high values of water absorption, due to the hygroscopic behavior of the wood together with the intrinsic porosity of the wood fibers and the increase in the porosity of the matrix, which allows the filling of existing voids by water.

\section{REFERENCES}

Ashori A, Tabarsa T, Amosi F. Evaluation of using waste timber railway sleepers in woodcement composite materials. Construction and Building Materials. 2012(27):126-9.

Associação Brasileira de Normas Técnicas ABNT. NBR 5733: Cimento Portland de alta resistência inicial. Rio de Janeiro: 1991.

Associação Brasileira de Normas Técnicas ABNT. NBR 7215: Cimento Portland -

Determinação da resistência à compressão. Rio de Janeiro: 1997.

Associação Brasileira de Normas Técnicas ABNT. NBR 8522: Concreto - Determinação dos módulos estáticos de elasticidade e de deformação e da curva tensão-deformação. Rio Janeiro: 2003.

Associação Brasileira de Normas Técnicas ABNT. NBR 9778: Argamassa e concreto endurecidos - Determinação da absorção de água, índice de vazios e massa específica Requisitos. Rio de Janeiro: 2005.

Associação Brasileira de Normas Técnicas ABNT. NBR 11768: Aditivos químicos para concreto de cimento Portland - Requisitos. Rio de Janeiro: 2011.

Associação Brasileira de Normas Técnicas ABNT. NBR 15630: Argamassa para assentamento e revestimento de paredes e tetos - Determinação do módulo de elasticidade dinâmico através da propagação de onda ultrasônica. Rio de Janeiro: 2008.

Associação Brasileira de Produtores de Florestas Plantadas- ABRAF. Anuário estatístico da ABRAF 2013 ano base 2012. Brasília: 2013. $146 \mathrm{p}$.

Barbosa LC, Pedrazzi C, Ferreira ES, Schneid GN, Wille VKD. Avaliação de resíduos de uma serraria para produção de celulose kraft. Ciência Florestal. 2014;24(2):491-500.

Beraldo AL, Carvalho JV. Compósito Eucalyptus grandis - cimento Portland. Scientia Forestalis. 2004(65):150-61. 
Bertolini MS, Campos CI, Souza AM, Panzera TH, Christoforo AL, Lahr FAR. Wood-cement composites from wastes of Pinus sp. wood: Effect of particles treatment. International Journal of Composite Materials. 2014;4(2):146-9.

Bouguerra A, Ledhem F, Berquin F, Dheilly RM, Quéneudec M. Effect of microstructure on the mechanical and thermal properties of lightweight concrete prepared from clay, cement, and wood aggregates. Cement and Concrete Research. 1998;28(8):1179-90.

Castro V, Araújo RD, Parchen C, Iwakiri S. Avaliação dos efeitos de pré-tratamentos da madeira de Eucalyptus benthamii Maiden \& Cambage no grau de compatibilidade com cimento Portland. Revista Árvore. 2014;38(5):935-42.

Christóforo AL, Ribeiro Filho SLM, Panzerai TH, Lahri FAR. Metodologia para o cálculo dos módulos de elasticidade longitudinal e transversal em vigas de madeira de dimensões estruturais. Ciência Rural. 2013;43(4):610-5.

Colerpadi M. Admixtures-enhancing concrete performance. In: Proceedings of the 6th.International Congress on Global Construction: Ultimate Concrete Opportunities. Dundee: ICGC, 2005.

Cunha AB, França MC, Almeida CCF, Gorski L, Cruz RC, Santos D. Avaliação do rendimento em madeira serrada de Eucalyptus benthamii e de Eucalyptus grandis por meio do desdobro tangencial e radial. Floresta. 2015;45(2):241-50.

*Fan M, Ndikontar MK, Zhou X, Ngamveng JH. Cement-bonded composites made from tropical woods: Compatibility of wood and cement. Construction and Building Materials. 2012;36:135-40.

Fagundes AHV. Produção de madeira serrada e geração de resíduos do processamento de madeira de florestas plantadas no Rio Grande do Sul [dissertação]. Porto Alegre: Universidade Federal do Rio Grande do Sul; 2003. 173p.

Frybort S, Mauritz R, Teischinger A, Muller U. Cement bonded composites - A mechanical review. BioResourches. 2008;2(3):602-26.

Garcez MR, Santos T, Gatto DA. Avaliação das propriedades físicas e mecânicas de concretos pré-moldados com adição de serragem em substituição ao agregado miúdo. Ciência \& Engenharia. 3013;22:95-104.

Gutierrez L, Cánovaz MF. The modulus of elasticity of high performance concrete, Materials and Structures. 1995;28:559-68.

Iwakiri S, Stinghen ABM, Silveira EL, Zamarian EHC, Prata JG, Bronoski M. Influência da massa específica sobre as propriedades mecânicas de painéis aglomerados. Floresta. 2008;38(3):486-93.

Jorge FC, Pereira C, Ferreira JMF. Wood-cement composites: a review. Holz Roh Werkst. 2004;62:370-7.

Lima JM, Iwakiri S. Utilização de resíduos da madeira de Pinus spp. como substituição ao agregado miúdo na produção de blocos de concreto para alvenaria estrutural. Ciência Florestal. 2014;24(1):223-35.

Lin X, Silsbee MR, Roy DM, Kessler R, Blankenhorn PR. Approaches to improve the properties of wood fiber reinforced cementitious composites. Cement and Concrete Research. 1994;24(8):1558-66.

Mendes LM, Loschi FAP, Paula LER, Mendes RF, Guimarães Júnior JB, Mori FA. Potencial de utilização da madeira de clones de Eucalyptus urophylla na produção de painéis cimentomadeira. Cerne. 2011;17(1):69-75.

Pehanicha JL, Blankenhorna PR, Silsbeeb MR. Wood fiber surface treatment level effects on selected mechanical properties of wood fibercement composites. Cement and Concrete Research. 2004(34):59-65.

Pimentel LL, Beraldo AL, Savastano Júnior H. Durabilidade de compósito biomassa vegetalcimento modificado por polímero. Engenharia Agrícola. 2006;26(2):344-53.

Ramos LMA, Ramos LMA, Latorraca JVF, Pastro MS, Souza MT, Garcia RA et al. Variação radial dos caracteres anatômicos da madeira de Eucalyptus grandis W. Hill Ex Maiden e idade de transição entre lenho juvenil e adulto, Scientia Forestalis. 2011;39(92):411-8. 
Ronquim RM, Ferro FS, Icimoto FH, Campos CI, Bertolini MS, Christoforo AL et al. Physical and mechanical properties of wood-cement composite with lignocellulosic grading waste variation.

International Journal of Composite Materials.2014;4(2):69-72.

Savastano Jr H. Materiais a base de cimento reforçados com fibra vegetal: Reciclagem de resíduos para a construção de baixo custo [livre docência] São Paulo: Escola Politécnica da Universidade de São Paulo; 2000. 187p.

Tessaro AB, Gonçalves MRF, Gatto DA, Pollnow EM, Carreño NLV, Delucis RA. Compósitos cimentícios reforçados com fibras de eucalipto puras e tratadas com tetraetilortossilicato (TEOS 98\%). Ambiente Construído. 2015;15(3):47-55.

Torkaman J, Ashori A, Momtazi AS. Using wood fiber waste, rice husk ash, and limestone powder waste as cement replacement materials for lightweight concrete blocks. Construction and Building Materials. 2014;50:432-6.

Yoshioka K, Tazawab E, Kawaib K, Enohata T. Adsorption characteristics of superplasticizers on cement component minerals. Cement and Concrete Research. 2002;32:1507-13. 